\title{
Plant Pest Biocontrol and its Status in Ethiopia
}

\section{Nega $R^{*}$}

Ethiopian Biodiversity Institute, Ethiopia

*Corresponding author: Roman Nega, Ethiopian biodiversity institute, Microbial

Directorate, Ethiopia, Tel: 0918169601; Email: romannega32@gmail.com

\section{Mini Review \\ Volume 3 Issue 4}

Received Date: November 16, 2019

Published Date: December 27, 2019

DOI: $10.23880 /$ ijoac- 16000177

\section{Abstract}

Biological control is a method of controlling pests (including insects, mites, weeds and plant diseases) using other living organisms. There are three basic types of biological pest control strategies: importation (sometimes called classical biological control), augmentation and conservation. Natural enemies of the pests, also known as biological control agents, include predatory and parasitic insects, predatory vertebrates, nematode parasites, protozoan parasites, and fungal, bacterial, as well as viral pathogens. The best known bacterial biological control which can be introduced in order to control butterfly caterpillars is Bacillus thuringiensis. Viruses most frequently considered for the control of insects (usually sawflies and Lepidoptera) are the occluded viruses, namely NPV, cytoplasmic polyhedrosis (CPV), granulosis (GV), and entomopox viruses (EPN), the fungus Trichoderma viride. This has been used against Dutch elm disease, and to treat the spread of fungal and bacterial growth on tree wounds. The significance of Biological control agents are nonpolluting and thus environmentally safe and acceptable. Usually they are species specific to targeted pest and weeds. The biological control discourages the use of environmentally and ecologically unsuitable chemicals, so it always leads to the establishment of natural balance. Ethiopia is one of the countries that use plant pest biocontrol methods mostly for weeds and insect pests.

Keywords: Controlling pests; Biocontrol; Pest management

Abbreviations: CPV: Cytoplasmic Polyhedrosis; GV: Granulosis; EPN: Entomopox viruses; IPM: Integrated Pest Management.

\section{Introduction}

Biological control, Biocontrol, or biological pest control is a method of suppressing or controlling the population of undesirable insects, other animals, or plants by the introduction, encouragement, or artificial increase of their natural enemies to economically non-important levels. It is an important component of integrated pest management (IPM) programs [1]. The biological control of pests and weeds relies on predation, parasitism, herbivores, or other natural mechanisms. Therefore, it is the active manipulation of natural phenomena in serving human purpose, working harmoniously with nature. A successful story of biological control of pests refer to the human beings' capability to depict natural processes for their use and can be the most harmless, non-polluting, and self-perpetuating control method [2].

Biological control is a method of controlling pests (including insects, mites, weeds and plant diseases) using other living organisms. It relies on predation, parasitism, herbivores, or other natural mechanisms, but typically 


\section{International Journal of Oceanography \& Aquaculture}

also involves an active human management role. It can be an important component of integrated pest management (IPM) programs [3]. There are three basic types of biological pest control strategies: importation (sometimes called classical biological control), augmentation and conservation [4].

In biological control, the reduction of pest populations is achieved by actively using natural enemies. Natural enemies of the pests, also known as biological control agents, include predatory and parasitoid insects, predatory vertebrates, nematode parasites, protozoan parasites, and fungal, bacterial, as well as viral pathogens [2]. Biological control agents of plant diseases are most often referred to as antagonists. Biological control agents of weeds include herbivores and plant pathogens. Pathogens are disease causing organisms including bacteria, fungi, and viruses. They kill or debilitate their host and are relatively specific to certain pest or weed groups [5].

Ethiopia is a country of huge bio-diversity and agricultural complexity. As in many developing countries, agriculture plays a key role in Ethiopia's economy. It provides employment for more than $80 \%$ of the population and contributes to nearly $50 \%$ of gross domestic product [6]. The major crops produced include cereals, legumes, oil seeds, roots and tubers, vegetables, fruit crops, coffee, spices and cotton. About 95\% of food production in Ethiopia comes from the peasant sector, where production technologies are primarily traditional [7].

Land holdings range between 0.5 and 3 ha or less, depending on the geographical region of the country. Land is prepared for planting by oxen drawing a local plough (the Marsha) or by manually operated hand tools. Sowing is done by broadcasting and weeding is dependent upon labor intensive practices. The use of irrigation, improved seed and other external inputs such as pesticides is minimal. Inter-cropping is a common practice. Patches of different crops (cereals and legumes, cereals and oilseeds, cereals and cereals, cereals and trees) are often grown side by side in the cereal-based systems of the central and northern Ethiopian highlands. Cropping patterns in the root crops-dominated southern Ethiopian highlands are characterized by even more heterogeneity [8]. Pest is Fungus, insect, nematode, rodent, weed, or other form of terrestrial or aquatic life form that is injurious to human or farm animal health, or interferes with economic activities such as agriculture.
Objective of this paper is to show Plant pest Biocontrol status in Ethiopia and to reduce the birth rate and increase death rate of pest.

\section{Review of Literature}

\section{Biological Control of Pest Plants}

Types of Niological Pest Control: There are three basic types of biological pest control strategies: importation (sometimes called classical biological control), augmentation and conservation [9].

\section{Importation}

Importation (or "classical biological control") involves the introduction of a pest's natural enemies to a new locale where they do not occur naturally. This is usually done by government authorities. In many instances the complex of natural enemies associated with a pest may be inadequate, a situation that can occur when a pest is accidentally introduced into a new geographic area, without its associated natural enemies. These introduced pests are referred to as exotic pests and comprise about $40 \%$ of the insect pests in the United States [4].

The process of importation involves determining the origin of the introduced pest and then collecting appropriate natural enemies associated with the pest or closely related species [10]. To obtain the needed natural enemies, we turn to classical biological control. This is the practice of importing, and releasing for establishment, natural enemies to control an introduced (exotic) pest, although it is also practiced against native insect pests [11]. There are many examples of successful classical biological control programs. One of the earliest successes was with the cottony cushion scale, a pest that was devastating the California citrus industry in the late 1800s. A predatory insect, the Vidalia beetle, and a parasitoid fly were introduced from Australia. Within a few years the cottony cushion scale was completely controlled by these introduced natural enemies [1].

It is usually most effective against exotic pests and less so against native insect pests. The reasons for failure are often not known, but may include the release of too few individuals, poor adaptation of the natural enemy to environmental conditions at the release location, and lack of synchrony between the life cycle of the natural enemy and host pest [12].

\section{Augmentation}

Augmentation involves the supplemental release of natural enemies, boosting the naturally occurring 


\section{International Journal of Oceanography \& Aquaculture}

population. Relatively few natural enemies may be released at a critical time of the season (inoculative release) or millions may be released (inundative release). An example of inoculative release occurs in greenhouse production of several crops [13]. The spraying of octopamine analogues (such as 3-FMC) has been suggested as a way to boost the effectiveness of augmentation Octopamine, regarded as the invertebrate counterpart of dopamine plays a role in activating the insects' flight-or-fight response [5].

The idea behind using octopamine analogues to augment biological control is that natural enemies will be more effective in their eradication of the pest, since the pest will be behaving in an unnatural way because its flight-or-fight mechanism has been activated. Octopamine analogues are purported to have two desirable characteristics for this type of application: they affect insects at very low dosages and they do not have a physiological effect in humans or other vertebrates [12].

Habitat or environmental manipulation is another form of augmentation. This tactic involves altering the cropping system to augment or enhance the effectiveness of a natural enemy. Many adult parasitoids and predators benefit from sources of nectar and the protection provided by refuges such as hedgerows, cover crops, and weedy borders [14].

\section{Conservation}

The conservation of existing natural enemies in an environment is the third method of biological pest control. Natural enemies are already adapted to the habitat and to the target pest, and their conservation can be simple and cost-effective [1]. Cropping systems can be modified to favor the natural enemies, a practice sometimes referred to as habitat manipulation. Providing a suitable habitat, such as a shelterbelt, hedgerow, or beetle bank where beneficial insects can live and reproduce, can help ensure the survival of populations of natural enemies. Nectar-rich plants that bloom for long periods are especially good, as many beneficial are nectivorous during the adult stage, but parasitic or predatory as larvae. A good example of this is the soldier beetle which is frequently found on flowers as an adult, but whose larvae eat aphids, caterpillars, grasshopper eggs, and other beetles [15].

These natural controls are important and need to be conserved and considered when making pest management decisions. In many instances the importance of natural enemies has not been adequately studied or does not become apparent until insecticide use is stopped or reduced. Often the best we can do is to recognize that these factors are present and minimize negative impacts on them. If an insecticide is needed, every effort should be made to use a selective material in a selective manner [3].

\section{Bio Controlling Pests using Pest Natural Enemies}

Predators: Predators feed on insects. Example: sevenspotted ladybird beetles kill aphid pests of small grains and alfalfa [15].

Parasitoids: Parasitoids are wasps or flies that lay their eggs on insect hosts; the young kill the host as they develop. Example: the wasp Macrocentrusgrandii lays its eggs on the European corn borer [16][11]

Diseases: Diseases that attack insects often occur in epidemics, killing off large numbers of insect pests. Example: the fungus Beauveria bassiana can cause local populations of European corn borers to die off [9].

Herbivores: Herbivores are insects that feed on weeds. Example: the weevil Rhyncocyllus has been introduced to feed on musk thistle seeds [17].

\section{Pathogens to be used as Biopesticides}

Various bacterial species are widely used in controlling the pests as well as weeds. The best-known bacterial biological control which can be introduced in order to control butterfly caterpillars is Bacillus thuringiensis, popularly called $B t$. This is available in sachets of dried spores, which are mixed with water and sprayed onto vulnerable plants such as brassicas and fruit trees. After ingestion of the bacterial preparation, the endotoxin liberated and activated in the midgut will kill the caterpillars, but leave other insects unharmed. There are strains of Bacillus thuringiensis that are effective against other insect larvae. Bacillus thuringiensis israelensis is effective against mosquito larvae and some midges [2].

Viruses most frequently considered for the control of insects (usually sawflies and Lepidoptera) are the occluded viruses, namely NPV, cytoplasmic polyhedrosis (CPV), granulosis (GV), and entomopox viruses (EPN). They do not infect vertebrates, non-arthropod invertebrates, microorganisms, and plants. The commercial use of virus insecticides has been limited by their high specificity and slow action [2].

Fungi are pathogenic agents to various organisms including the pests and the weeds. This feature is intensively used in biocontrol. The entomopathogenic 


\section{International Journal of Oceanography \& Aquaculture}

fungi, like Metarhizium anisopliae, Beauveria bassiana, and so forth cause death to the host by the secretion of toxins. A biological control being developed for use in the treatment of plant disease is the fungus Trichoderma viride. This has been used against Dutch elm disease, and to treat the spread of fungal and bacterial growth on tree wounds. It may also have potential as a means of combating silver leaf disease [18].

\section{Effects of Biological Control}

Biological control can potentially have positive and negative effects on biodiversity [19]. The most common problems with biological control occur via predation, parasitism, pathogenicity, competition, or other attacks on non-target species. Often a biological control agent is imported into an area to reduce the competitive advantage of an exotic species that has previously invaded or been introduced there, the aim being to thereby protect the existing native species and ecology. However the introduced control does not always target only the intended species; it can also target native species $[10,19]$. The significance of Biological control agents are non-polluting and thus environmentally safe and acceptable. Usually they are species specific to targeted pest and weeds. The biological control discourages the use of environmentally and ecologically unsuitable chemicals, so it always leads to the establishment of natural balance [19].

\section{Ethiopian Biocontrol Techniques}

Ethiopia is one of the countries affected by invasive plant species, which have been clearly identified as one of the emerging problems facing the country [8]. Biological control using insects, pathogens or other organisms has an important role to play as a management tool as part of an integrated pest management strategy. Small-scale farmers may not be able to invest on management options for invasive alien plant species. Control of these species in pasture, fallow and wastelands, grazing land, water bodies and roadsides in urban and rural situations is more crucial than crop fields. However, farmers do not control weeds in non-crop lands in Ethiopia although any control measure undertaken to reduce or eliminate will benefit them directly [6].

Hence, integrated management involving biological control will be of direct benefit to them. Furthermore, invasive plants present a major threat to the rest of Africa, and its containment in Ethiopia will help to protect neighboring countries from its impact [20].There are two techniques or approaches used in biological control: Classical biological control and non-classical biological control. The classical biological control involves introduction of natural enemies from their native range into an exotic range. It is the most commonly used technique. Whereas the non-classical biological control concentrates on use of native natural enemies as inundative (release of large numbers of the agent to control the target $[21,22]$.

\section{Summary}

The aim of this study was to address Biocontrol methods of plant pest based on the literature review results the following summery were drown.

1. Plant pests can be controlled using microorganisms some natural enemies, Biocontrol agents etc.

2. Use of Biocontrol is to reduce the pesticides, environmental contaminates and health risk to animals and humans.

3. Strategies using biological control includes create welcoming Environment and to released natural enemies. 4. Biocontrol of pests have some disadvantages includes it takes long period of time (5-10 years) and also it requires governmental supports, require high initial investment, and technology can not be sold.

5. Ethiopia is one of the countries that use plant pest biocontrol methods mostly for weeds and insect pests.

\section{Recommendation}

- National capability in pest biological control should be developed in Ethiopia in order to address the problem.

- Introduction and release of pest biological control agents that involves the FAO guide line should be developed in Ethiopia.

- Capacity building in terms of quarantine greenhouses for host specificity and evaluation studies, equipments, man power development through trainings and exchange of experiences from countries where biological control of pest have been successful are mandatory for effective management of the invasive pest problems in the country.

\section{References}

1. Weeden CR, Shelton AM, Hoffman MP (2007) Biological control: A guide to natural enemies in North America. Cornell University College of Agriculture and Life Sciences.

2. Metcalf CL, Flint WP, Metcalf RL (1973) Destructive and Useful Insects, Their Habitats, and Control. 4(Edn.), Tata McGraw-Hill Publishing Company, New Delhi. 


\section{International Journal of Oceanography \& Aquaculture}

3. Wan FH, Wang R (1991) Achievement of biological control in the world and its prospect in China (in Chinese). Chinese Journal of Biological Control.

4. DigGood (2007) Notes on natural pest control for an organic garden. DigGood.com.

5. Denton GRW, Muniappan R, Marutani M (1991) Status and natural enemies of the weed, Lantana camara, in Micronesia. Tropical Pest Management 37(4): 338-344.

6. Rebka G (2006) Survey of pathogenic fungi on Striga in North Shewa, Ethiopia and assessment for their biocontrol potential. MSc Thesis. Haramaya University, Haramaya, Ethiopia, pp: 65.

7. Fasil R (2004) A Review of striga management in Eastern Africa. Pest Management Journal of Ethiopia 8: $1-12$.

8. EARO (2004) UNDP/GEF National Project DocumentEthiopia.

9. Lawrence L (2005) Biocontrol: An overview of biological control research in CSIRO Entomology. CSIRO Australia.

10. HP (2007) Biological control. Helicon Publishing, Research Machines plc.

11. Smart GC (1995) Entomopathogenic nematodes for the biological control of insects. Journal of Nematology 27(4S): 529-534.

12. Broughton S (2000) Review and evaluation of lantana biocontrol programs. Biological Control 17: 272-286.

13. Mahadevappa M, Patil VC (1997) Proceedings of the 1st International Conference on Parthenium Management. University of Agricultural Sciences, Dahrwad, India, pp: 63-69.

14. Hoddle MS, Grandgirard J, Petit J, Roderick GK, Davies N (2006) Glassy-winged sharpshooter Ko'ed-First round-in French Polynesia. Biocontrol News and Information 27(3): 47-62.

15. Hein, Gary L (2007) Use of predators to control insect pests in potato. University of Nebraska-Lincoln.

16. Parker C, Riches CR (1993) Parasitic weeds of the world: biology and control. CABI, Wallingford, UK.

17. Kroschel J, Abbasher AA, Sauerborn J (1995) Herbivores of Striga hermonthica in northern Ghana and approaches to their use as biocontrol agents. Biocontrol Science and Technology 5(2): 163-164.

18. Shanks CH, Agudelo-Silva F (1990) Field pathogenicity and persistence of heterorhabditid and steinernematid nematodes (Nematoda) infecting black vine weevil larvae (Coteoptera: Curculionidae) in cranberry bogs. Journal of Economical Entomology 83: 107.

19. CNR (2007) Economics of biological control. College of Natural Resources, University of California, Berkeley.

20. Julien M (1997) Biological control of weeds: An illustrated seminar. In: Julien M, White G (Eds.), Biological control of weeds: theory and application. Australian Center for International Agricultural Research Monograph, pp: 1-8

21. Adkins S (1997) Introduction to weed science. In: Julien M, White G (Eds.), Biological control of weeds: theory and application. Australian Center for International Agricultural Research, pp: 23-38.

22. Auld BA (1997) Bioherbicides. In: Julien M, White G (Eds.), Biological control of weeds: theory and application Biological control of weeds: theory and application. Australian Center for International Agricultural Research, Monograph, pp: 129-134. 